\title{
Provincial Oversight and University Autonomy in Canada: Findings of a Comparative Study of Canadian University Governance
}

\author{
Julia Eastman \\ University of Victoria \\ Glen A. Jones \\ OISE, University of Toronto \\ Olivier Bégin-Caouette \\ Université de Montréal \\ Sharon X. Li \\ OISE, University of Toronto \\ Christian Noumi \\ OISE, University of Toronto \\ Claude Trottier \\ Université Laval
}

\begin{abstract}
In order to fulfill their missions, research universities must maintain conditions and capacity for knowledge production and dissemination, while responding to the expectations of governments, other stakeholders, and/or markets. That universities succeed in this quest is vital, not only for their own future as organizations but also for the benefit of current and future generations of students, stakeholders, and society at large. We sought to contribute to the understanding of how higher education institutions and systems rise to the challenge of achieving and sustaining relative institutional autonomy by conducting a comparative case study of the governance of six major uni-
\end{abstract}


versities in five provinces in Canada. This article presents our findings with respect to provincial oversight of the case universities. We found that the case universities appeared to be coming from and to remain at different points on a state supervision/autonomy continuum, but all appeared to be experiencing greater provincial supervision.

\section{Résumé}

Afin d'accomplir leurs missions, les universités à forte intensité de recherche se doivent de maintenir les conditions nécessaires à la production et à la diffusion des connaissances, tout en répondant aux attentes des gouvernements, des marchés et d'autres acteurs. L'atteinte de cet équilibre est vitale, non seulement pour leur propre avenir en tant qu'organisations, mais également pour les étudiants actuels et futurs, les acteurs universitaires et la société dans son ensemble. Cet article compare les études de cas de six grandes universités dans cinq provinces canadiennes afin de mieux comprendre comment les universités et les systèmes d'enseignement supérieur parviennent à préserver une autonomie institutionnelle relative. Nos résultats suggèrent que les universités se situent à différents points sur un continuum autonomie/ contrôle étatique, mais aussi que toutes les universités sont assujetties à un contrôle provincial accru.

\section{Introduction}

Universities have become one of the most important institutions in society. As Marginson (2015) has noted, "higher education has become an essential passport to full-time work and effective social status" (p. 11), and participation rates have increased throughout the world, with more than half of the traditional age cohort now enrolling in institutions of higher education in many countries, including Canada (Cantwell, Marginson, \& Smolentseva, 2018). In addition to universities' educational function, enormous emphasis is now placed on university research in an era where knowledge production is linked to national economic development and innovation.

Given their importance, there is an increasing interest in how universities can and should be governed (Austin \& Jones, 2015). How can public universities respond to the complex needs of their multiple stakeholders while at the same time retaining the independence needed to establish the necessary conditions for knowledge creation and dissemination? This question is particularly challenging for research universities, which "although powerful...are also fragile institutions, requiring autonomy, shared governance and academic freedom" (Altbach, 2015, p. 4).

We sought to contribute to the understanding of how higher education systems and institutions rise to this challenge in Canada by conducting a comparative case study of the governance of six major universities in five provinces. The study examined both their external and their internal governance. This paper presents findings from one component of this larger study, the provincial oversight of the case universities. We begin the paper with a review of the conceptual underpinnings of our work, followed by a description of our methodology, the presentation of findings from our cross-case analysis, and our concluding observations. 


\section{Conceptual Foundation}

Following Harman (1991), we defined governance as referring to "how higher education systems and institutions are organized and managed, how authority is distributed and exercised, and how both systems and institutions relate to governments" (p. 1280). Governance is multilayered, with institutional governance structures operating within a framework of government and system-level coordination.

The concept of "institutional autonomy" has been commonly used as a tool for understanding the ways in which the authority of institutional governance structures is limited by the external environment. Like Thorens (2006) and others, we understand autonomy as the freedom that allows the institution to organize itself so as to carry out its mission effectively and academic freedom as the right and duty of university professors to advance and disseminate knowledge without constraint. The extent of universities' autonomy has and does vary greatly across time and within and between jurisdictions, depending on national traditions, whether universities are public or private or both, whether states are centralized or federations, and other factors (Thorens, 2006). Although university autonomy is neither a necessary nor a sufficient condition for academic freedom, "it can hardly be denied that there is a link between institutional autonomy and individual academic freedom" (Barendt, 2010, p. 67).

More than 50 years ago, Ashby and Anderson (1966) identified as key ingredients of university autonomy institutional freedom over the selection of students, recruitment of staff, setting of standards, awarding of degrees, design of curriculum, and allocation of funds, as well as freedom from non-academic interference in the academic governance of the institution (p. 296). Since then, the relationship between universities, government, business, and society has changed and jurisdiction over matters such as these has become more ambiguous (Henkel, 2007). Henkel (2007) notes that "boundaries have become fuzzy, movable and permeable" (p. 93) and "institutional and individual academic autonomy is not given under these circumstances, so much as continually to be striven for and won" (p. 98).

Various studies have sought to measure the degree of autonomy available to universities in different jurisdictions. Studies in which Canada and/or Quebec have been included (e.g., Richardson \& Fielden, 1997; Anderson \& Johnson, 1998; Jamet, 2014; Lacroix \& Maheu, 2015) have found Canadian universities to be relatively highly autonomous from government. Echoing this view, Cameron concluded his 1991 book on universities, government, and public policy in Canada with the observation that "provincial policy has been remarkably respectful of institutional autonomy. Universities have nowhere in Canada become mere agents of provincial governments, and there is no indication that any province seriously intends to have it otherwise" (p. 446).

Writing several years later, Skolnik (1997) nevertheless discerned interprovincial variations. "In addressing the inevitable tension between provincial accountability and institutional autonomy, some [provinces] have tilted the balance toward accountability, while others have retained emphasis on autonomy" (p. 335). He cited Alberta and British Columbia (BC) as provinces that had attempted to "take some steps toward creating a comprehensive plan or vision" (p. 336). Fisher, Rubenson, Shanahan, and Trottier (2014), comparing the development of post-secondary systems in BC, Ontario, and Quebec from 1980 to 2010, identified Quebec as the province that had approached post-secondary planning and policy with a system orientation (p. 337). 
The primary focus of previous studies of university autonomy in Canada has been on the provincial "system" through an exploration of system-level policy and governance. In our study we shift the unit of analysis down to the level of the institution: how do specific universities experience institutional autonomy in the context of provincial systems? What can we learn by looking across these institutional experiences in different Canadian jurisdictions?

Our work has also been influenced by Pierre Bourdieu (1993), who distinguished between fields of restricted cultural production (where autonomous producers create cultural goods for other producers), and fields of large-scale production (where investments are driven by the quest for markets and profits, with production addressing pre-existing external needs and producers who are subordinate to those who control the mechanisms of production and diffusion). Drawing on Bourdieu's distinction between these two important forms of production, we believe that a key consideration in university governance is how institutions can maintain relative autonomy-in other words, how they can respond effectively to the expectations of governments, other external stakeholders, and/ or markets and thereby secure resources, while sustaining conditions and capacity for knowledge production and dissemination. On the one hand, in order for universities to fulfill their functions of production and dissemination of knowledge-and, ultimately, their roles in global society-universities need to operate in an environment in which faculty members exercise academic freedom and in which academic expertise and considerations inform decision-making. On the other hand, higher education systems and universities do not operate in a vacuum. They must contribute to the social and economic development of society, meet students' needs and expectations, and be responsive to external stakeholders. Moreover, universities that are public institutions or publicly funded must be accountable to governments for their management of funds and the quality of their programs, research, and services to the community.

How is it possible to reconcile these requirements - the need for universities to be responsive and accountable to stakeholders, while fostering the exercise of academic judgement and academic freedom?

\section{Research Methodology}

The principal phase of the research, which took place between 2012 and 2014, involved the collection of information about six major universities in five provinces, located in different regions of Canada. Five of the universities were the largest, most research-intensive, medical/doctoral universities in their respective provinces. In Quebec, where universities operate under two different legislative frameworks, two universities-one within and one outside the University of Quebec-were included. The case universities were Dalhousie University (Nova Scotia); l'Université de Montréal (Quebec); l'Université du Québec à Montréal (Quebec); the University of Toronto (Ontario); the University of Alberta (Alberta); and the University of British Columbia (BC). These are highly distinctive institutions and our findings should not be seen as representative of the experience of other universities.

Data for five provincial studies (one comprising both Quebec universities) were obtained from analysis of institutional and government documents and reports and detailed open-ended interviews with university officials and members, government officials, and others within the sector in each province, including student and faculty association leaders. 
In total, 86 interviews were conducted at the provincial and institutional levels. We then compared the data collected about the state-level governance and institutional governance of the six universities along numerous dimensions, to identify the following: commonalities and differences amongst provinces and case universities; changes over time; implications for the governance of the universities and their relative autonomy; and insights into how the external and internal governance of the universities fostered the exercise of academic judgement and responsiveness to the needs and demands of external stakeholders.

\section{External Governance of Universities in Canada}

The great majority of Canada's approximately 100 universities are not-for-profit corporations, established by acts of provincial legislatures. Some were founded by colonial or (after 1867) provincial governments; others were sponsored by churches or private benefactors (Lang, 2005). As independent corporations, they traditionally had the capacity to enter into contracts, own assets, determine employment arrangements, allocate funds internally, and so on. Although the great majority are public (in that they receive operating funding from provincial governments), there are major differences between institutions in terms of size and program mix, and the sector is highly stratified. At the top of the hierarchy are a handful of institutions that meet Altbach and Balan's (2007) definition of a research university (p. 6) and are ranked amongst the global university elite. Most of the case universities in this study meet this definition, being the flagship universities in their respective provinces.

The provincial governance of the case universities was similar insofar as the latter all operated under provincial legislation, they all received provincial operating funding, there were similarities in the policy and regulatory regimes to which they were subject, and provincial governments appointed some of the members of their boards. That said, there were also differences in several of the dimensions discussed below, the significance of which emerged from the cross-case analysis. In the sections that follow, we describe these dimensions of the universities' external governance before summarizing the implications for their autonomy.

\section{Historical Context}

Differences in the histories of universities in the five provinces and of their relationships to government appeared to continue to shape their external governance. The historical contexts of universities in the five provinces varied greatly, because the founding of universities reflected patterns in the settlement and colonization of what is now Canada (Jones, 1997). In general, the original universities in the East were older, initially affiliated with churches, and historically largely private; in contrast, the universities in British Columbia and Alberta were established by the state as secular, public institutions intended to serve the whole province. With massification in the 1960s and the Quiet Revolution in Quebec, a new series of secular, public institutions was established (Jones, 1996). At the time of our study, major differences persisted amongst the five provinces. At one end of the spectrum, the Nova Scotia government of the day regarded the province's universities as autonomous and did not want to control them or have them on the government's books; at the other, the Alberta government treated Campus Alberta (the provincial system of post-secondary edu- 
cational institutions and coordinating bodies) very much as part of the public sector. The Quebec higher education system had many distinctive features, including a unique college sector and a provincial university network alongside the charter universities.

\section{Institutional Arrangements}

Each of the provincial governments had a department or ministry responsible for policy and programs related to universities, as well as for colleges and other post-secondary institutions. In some cases, the department also had responsibility for science and innovation policy, and in others, for labour market initiatives and training. Universities interacted at the provincial government level, not only with the department or ministry of higher education, but also with other departments of government (e.g., science and technology, labour, health, forestry, or agriculture), the objectives, policies, and programs of which might or might not be aligned with each other. In some provinces, other bodies played roles in the external governance of universities-either by virtue of their own authority or through the provision of advice to governments-from the Maritime Provinces Higher Education Commission to the Superior Council of Education in Quebec to the more recently established Higher Education Quality Council of Ontario.

In four of the five provinces, universities advocated with their respective provincial governments collectively as well as individually to varying degrees, through organizations like the Research Universities Council of BC or the Council of Ontario Universities. (Quebec was an exception at the time of our study.)

The provincial governments provided large amounts of funding to universities and naturally had expectations in return. In our interviews, an Ontario official said:

While we may expect different things from different institutions in the system, depending on their mandate and areas of strength and excellence, our overall approach (from the government point of view) will be one of setting government policy within which the universities operate and using funding levers to achieve the policy objectives. We transfer $\$ 3.5$ billion in operating transfers to the 20 universities. So, in exchange for our writing those cheques, there are some expectations, I guess, with respect to accountability and alignment with government policy objectives, and achieving some value for money.

\section{Legislative Framework}

There were differences between provinces in whether universities operated under a post-secondary sector act (Alberta), a university system act (BC), individual acts (Ontario, Nova Scotia), or both university system and individual acts (Quebec). The existence of an individual act appeared to create a different dynamic between the university and the government than existed where there were collective acts. Insofar as universities operating under collective acts tended to get swept up in legislative changes aimed at the sector at large-or intended to address situations at other institutions-universities with their own acts appeared to have somewhat more control over their governance.

The legislation under which the case universities operated was of very different longevity -Dalhousie (Dal; 1863), l'Université de Montréal (U de M; 1967), l'Université du Québec (UQ; 1968), University of Toronto (UT; 1971), University of British Columbia (UBC; 1996), 
and University of Alberta (U of A; 2004)-and the acts varied in levels of specificity and prescriptiveness. "The act" seemed to figure much more prominently in the thinking of university and government officials in some provinces than in others. Case universities appeared to have different attitudes to or relationships with their acts. Some relied on aspects of the legislation to maintain their autonomy. For example, UQAM had obtained a special status within the UQ - that of an "associated university" - of which it was proud and which enabled it to recommend the appointment of its rector directly to the Quebec government, to grant degrees, and to enter into agreements with other institutions.

Officials at both Dal and U de M regarded aspects of their acts as less than optimal but were, at the time of the interviews, reluctant to seek revisions for fear of opening themselves up to unwanted changes. It appeared that university officials, even if they regarded their acts as imperfect, sought changes with some trepidation for fear of losing provisions that they deemed important. One sensed that they would pick their moments carefully-if possible, waiting until there was a government in power that would look favourably on what was proposed and be unlikely to introduce other changes.

The comments of a government official interviewed in Alberta suggested that governments also pick their moments carefully in opening up legislation. The official said, "Obviously, you do that in political cycles, right?...So if there's going to be any legislative changes, those would likely follow [an election], probably in the first year of the government mandate."

The governing structures provided for under the acts differed significantly: four of the institutions were bicameral (Dal, UQAM, U of A, and UBC); one was tricameral (U de $\mathrm{M}$ ); and one unicameral (U of T). There was diversity even amongst the bicameral institutions: UBC had a senate for each of its two campuses; U of A had a general faculties council (an academic senate) as well as a largely advisory "senate" composed mainly of community volunteers from across the province; and UQAM was part of the governance structure of the UQ. For those universities with boards or equivalents, external members were in the majority (counting alumni as "external"), except in the case of UQAM, where the board had an internal majority. Although the existence of a majority of external members on university boards appeared to be taken for granted in most of the country, the appropriate balance between internal and external board members had been and remained a major issue in Quebec.

\section{Accounting Status}

Provinces differed in whether they were deemed for accounting purposes to "control" their universities and in whether universities were within the government reporting entity (GRE). The GRE consists of the departments, agencies, boards, commissions, Crown corporations, and not-for-profit organizations whose finances are reported as part of a provincial government's financial statements. The Public Sector Accounting Board (PSAB) of the Chartered Professional Accountants of Canada establishes generally accepted accounting principles (GAAP) for senior governments in Canada. This includes setting standards for determining which organizations are within and which are outside the reporting entity. The fundamental principle is that "[a government's] reporting entity comprises all organizations controlled by that government" (PSAB, p. 7). The PSAB provides a definition of control and various indicators to assist governments to determine which organiza- 
tions are within their control. In Nova Scotia and Ontario, universities were deemed to be outside the control of government and hence outside the GRE. In BC and Alberta, they were within. In Quebec, charter universities were outside whereas the UQ was within the GRE. Because the universities in BC and Alberta were within those provinces' GREs, they had less authority over their finances than universities in Nova Scotia and Ontario, and their capacity to respond to other needs (e.g., to borrow money to build infrastructure or residences) tended to be correspondingly less. Although charter universities in Quebec were outside the GRE, all Quebec universities were required by law to obtain provincial approval for major infrastructure projects.

\section{Provincial Policy and Regulatory Mechanisms}

All five provincial governments appeared to be seeking to align universities' activities or outcomes more closely with desired public policy goals. Officials interviewed in several provinces and at the federal level suggested that there was what one described as "convergence in terms of an interest in university governance, transparency, accountability, value for money, and alignment with government's public policy priorities" on the part not only of provincial governments in Canada, but also of jurisdictions abroad.

Provincial governments were described as increasingly concerned to ensure that universities' activities address labour market needs and contribute to economic growth and innovation. The instruments that the provincial governments were employing or contemplating varied from mandate letters or MOUs to funding mechanisms to legislation, official policy statements (énoncés de politique), and regulations. In some cases, a province appeared to have adopted an idea from another one (e.g., the practice of providing a government letter of expectation to universities). Quebec universities were required to report annually to the Commission de la culture et de l'éducation de l'Assemblée national and to appear before the commission every three years.

In all provinces, the amount of regulation and accountability requirements was said to have increased substantially in recent years. In Nova Scotia, government and university officials both described the provincial government as expecting more from the universities, while reducing funding. In Quebec, the amount of legislation and regulation had increased dramatically over the course of the previous decade: government officials acknowledged that the volume had become excessive and had undertaken to lessen the regulatory burden. In Ontario, reporting requirements were also described as having increased significantly. In Alberta, recent government initiatives had extended beyond increased accountability and reporting. The previous minister was said to have sought to transform Campus Alberta into "a semi-official entity that allocated programs among institutions and compelled them to join that activity in a much more ministerial-directed entity with 26 moving parts [i.e., institutions]." The minister in question had, in the words of one interviewee,

wanted to brand all of us under Campus Alberta with pins and logos and we would go to the world as "Campus Alberta," lower case university of Alberta. That would be a disaster because, while we don't like rankings for all kinds of sound reasons, the world does and we would never get Campus Alberta ranked, and if you did, it wouldn't do very well. So we need an identity internationally to compete and you 
have to be roughly top 100 to get any attention from that peer group, and if they can't find you because you've been pushed into Campus Alberta, then quite literally they won't talk to you.

Fortunately, from the point of view of the universities, the former minister's conception of Campus Alberta had not come to fruition.

In BC, university boards were not allowed to borrow, sell assets, sign collective agreements, set executive compensation, or establish new academic programs without government approval. (Because of UBC's land holdings, it was effectively able to borrow from itself, but it nevertheless faced other constraints arising from being within the GRE.) In $\mathrm{BC}$ and Alberta, one of the factors driving increased regulation was inclusion in the Government Reporting Entity. Historically, most Canadian universities have not been part of provincial governments' reporting entities, with a few exceptions (e.g., UQ institutions and two universities in Manitoba). BC universities were moved into the GRE in the wake of a recommendation from the province's auditor general in 2003. Alberta universities were included in the GRE in the same year in response to changes in the Public Sector Accounting Board (PSAB) Handbook.

\section{Provincial Roles Relative to Institutional Governance and Leadership}

In Alberta, the province appointed the university's board chair and all non-ex officio board members, some as public board members and the rest upon nomination by constituency groups. The provincial government was said to run "the process [for appointing the chair and public members] very much like filling a human resource vacancy...in government." In BC, the government appointed more than half the members of a university board (including alumni association nominees). In contrast, order-in-council appointees made up less than one-third of the members of the University of Toronto's governing council and approximately one-third of the Universite de Montréal's board, and the Nova Scotia government made appointments to the Dalhousie board only upon nomination by that board. With the exception of the rector, the members of the board of UQAM were all appointed by government, most upon designation by university bodies or groups, and some as representatives of the college sector and of social, cultural, business, and labour communities.

Most of the case universities recommended to government external candidates for appointment to their boards, using some form of skills matrix to identify and assess candidates for particular vacancies. In the case of Alberta, the process was unique in that it was the provincial government that sought applications and assessed them and provided the university board chair with an opportunity for input before making an appointment. Interviewees knowledgeable about the appointment processes at the case universities said that government normally appointed board members from amongst their nominees. (At Dalhousie, it was a requirement of the legislation that government do so.)

At five of the six universities, the president or rector was appointed by the board. At UQAM, the rector was formally appointed by the government upon the recommendation of the UQAM board of directors, but this took place after a consultation by means of a ballot and the process was described by interviewees as an election. Although, apart from UQAM, provincial governments did not play a role in the appointment of the president, in $\mathrm{BC}$, presidential compensation required approval by the province's Public Sector Employers Council. 
There were differences between provinces in the ways that governments related to universities. In Nova Scotia, Quebec, and Ontario, presidents were the principal interlocutors with governments on behalf of their institutions. A board chair might accompany a president in meeting with a minister or other government official on a particularly important occasion-and/or board chairs might receive periodic communications from government to make sure they were aware of developments or obligations-but it was normally the president with whom government communicated. Depending on their particular backgrounds and connections, board leaders or members might communicate with government officials on particular issues, but it would typically be at the request of the president or rector rather than at the behest of government. By contrast, in Alberta, there were direct and formal relations between government officials and board chairs (Alberta, 2013). The latter were the conduit between their institution and the provincial government. According to interviewees, "in Alberta amongst the senior public service, its board chair speaks to minister, president speaks to deputy minister." Above and beyond its relations with the board chair, the Alberta government sought to ensure that all public board members knew that they were there to act in the best interests of the province and taxpayers. In BC, the government also required board chairs to sign government letters of expectation (since replaced by government mandate letters) on behalf of the universities.

Although presidents (rather than board chairs) were described as the principal interlocutors with governments in most provinces involved in this study, it appeared that roles might be evolving. For example, board chairs in Ontario had begun meeting together and had recently undertaken to organize an annual governance conference, with the assistance of the Council of Ontario Universities. At the same time, the Ontario government was beginning to see chairs as an important group and to communicate with them. An official said:

This represents a little bit of a shift from the past. I think they are playing a stronger role as a board and board chairs. And having conversations with the Ministry. We're encouraging them to diplomatically evaluate management strategies and challenge the president in ways that are helpful and constructive, and their management teams for making those decisions for the institution.

\section{Impact of Provincial Politics, Policy, and Public Administration}

Notwithstanding the many similarities in provincial governments' goals vis-à-vis universities at the time of the interviews, their goals varied in specifics and in flavour, and there were differences in how the governments pursued them. Interviews at the provincial and federal levels suggested that governments' goals with respect to universities, while exhibiting considerable continuity across provinces and across time within provinces (e.g., contribution to economic growth), also varied to some degree with the party in power. In Quebec, the government had changed from the time of the interviews (2013-14), when the Parti Québécois (PQ) was in power, to the time of writing the Quebec case report (2015), when the Liberals again formed government. Both Liberal and PQ governments appeared to seek to strengthen the links between higher education and business in order for Quebec to better compete in the global economy, and both parties followed the trend initiated in the 1970s to support research that would contribute to the development of Quebec 
(Fournier \& Maheu, 1975). That said, the Parti Québécois government had chosen to put more emphasis on access relative to economic outcomes. Amongst its other initiatives, the PQ government had also introduced into the National Assembly in the fall of 2013 a charter of secular values that would have prohibited public sector employees-including university employees-from wearing religious symbols (e.g., turban, hijab, kippah). This would have affected not only faculty and staff but also students employed as teaching or research assistants. The rectors of numerous charter universities and the rector of UQAM publicly opposed the proposed legislation, on grounds including infringement of university autonomy (Charbonneau, 2014). The bill did not become law, but it was an example of the type of legislative initiative (an extreme example being "campus carry" legislation enacted by some American state governments) that can have a profound impact on life on the ground on university campuses. Above and beyond variations in policy emphasis between governments of different political stripes, there appeared to be variations in the nature and strength of governments' relationships with stakeholders. For example, interviewees indicated that the Parti Québécois government in power in 2013 was in communication with student and faculty union leaders to a much greater extent than the previous Liberal government. The impact of a change in government on universities was also seen in Alberta after the research for this study.

The nature of the relationships between governments and universities naturally varied between provinces. Some very positive things were said by interviewees representing both "parties." At the same time, there appeared to be elements of mutual frustration and incomprehension between university and government officials. To the latter, universities could appear unresponsive, intransigent, and ungrateful for the massive public funding they received. For their part, many university officials interviewed said that members of the provincial ministry or department responsible for higher education had little understanding of universities.

Even in some large provinces, it was observed that ministries lacked strong policy capacity. (As one university official observed, lack of policy capacity could be a blessing: "In a way, it's lucky because if they really had the capacity to drive what they say they want to do, I'd be worried.") The result, however, was that government policies were often out of touch with institutional realities and did not achieve their intended objectives.

University and other interviewees indicated that ministries or departments tended to be restructured every few years and that not only ministers but also deputy ministers and assistant deputy ministers turned over frequently, causing discontinuity in relationships and the need to orient people anew. A number of government officials acknowledged this phenomenon and suggested it was not likely to diminish.

One long-serving official, who had had the opportunity of observing the interaction of provincial officials with university officials for many years, identified several factors that may help explain the nature of the government-university relationship:

- Deputy and assistant deputy ministers have complex and demanding jobs and tend to serve for relatively short periods in any given department.

- Those serving in the department or ministry of higher education may have little understanding of how universities are governed and how that constrains the authority of presidents and boards and may apply to universities approaches originating in other sectors. 
- Finally, governments and universities operate on different time scales. Whereas "governments change visions every time a new government is elected," and senior officials naturally pursue what ministers want, universities tend to have longerterm agendas.

An additional factor, identified by an Alberta official, was that in a province, the "revenue reality [of which] change[s] very dramatically on an annual basis...the expectations of resource availability from institutions doesn't necessarily match up with government's ability to provide that level of stability on an annual basis."

\section{Summary of Findings Regarding Provincial Governance}

In sum, it appeared that, in their relationships with provincial governments, the case universities embodied different traditions of university governance and autonomy. All were experiencing increased state supervision, but they were coming from and remained at different points on the state supervision/autonomy continuum. By and large, universities in Nova Scotia and Ontario appeared to be more independent of government than those in the West (e.g., they had individual acts rather than a common act; proportionately fewer government appointees on boards; were outside the government reporting entity [GRE]; and received a relatively low proportion of their total revenue from the province). The Alberta university sector appeared to be the most public insofar as board chairs were appointed by the provincial government (which advertised and conducted a search and selection process) and were deemed to be responsible and accountable to the minister. Quebec was unique in that, although all universities in the province were subject to common policy and funding regimes, the province had both charter universities (which had individual acts, proportionately fewer board members appointed by government, and rectors who were not appointed by government, and were outside the GRE) and l'Université du Québec (where the UQ president was appointed by government, the rectors were appointed by government, board members were appointed by governmentsome upon nomination by their constituencies, rectors' compensation was regulated by government, and the UQ was within the provincial GRE).

Whether universities in a given jurisdiction are public or private depends on a number of factors, including legal status, control, finance, and common usage (Levy, 1986). Public or private status is thus more ambiguous than status relative to the government reporting entity. Although, with a very small number of exceptions, Canadian universities are regarded as public, we found that the status of universities in relation to the public sector appeared to differ significantly amongst the five provinces. Whereas a Report on the University System prepared by Tim O’Neill for Nova Scotia's premier in September 2010 said that "universities are independent entities, not government departments" (O'Neill, 2010, p. 16), in BC and Alberta universities were deemed to be part of the public sector (and were within the GRE). A university official in Alberta said, "We have no degree of separation from the Crown. We are viewed by the auditor general as part of the government and the only difference between the department and the university is that we are part of the broader public sector." In Quebec, universities' statuses differed for accounting purposes (charter universities being outside the government reporting entity and UQ institutions within it), but all universities were deemed to be public for other specific purposes (e.g., under the Loi sur l'accès aux documents des organismes publics [LRQ, C A-2.1]). 
There were instances in $\mathrm{BC}$ and Alberta, but also in other provinces, of policies, procedures, and mechanisms developed for other parts of the public sector being applied to universities. At a more general level, the adoption of new public management principles in Quebec and other provinces in prior decades, with corresponding increases in emphasis on accountability, informed provincial governance of the university sector.

Provincial governments' efforts to put in place mechanisms to make universities accountable for meeting public policy goals and targets creates tension within the institutions, because governments' expectations of universities' behaviour tend to be inconsistent with universities' internal governance structures, policies, and cultures. As noted at the outset, research universities need shared governance and academic freedom in order to succeed in their missions. In the course of our research, interviewees identified many factors that foster and protect the exercise of academic judgement and academic freedom, including bicameral governance structures, institutional policies and collective agreements, leadership, culture, and norms. While these may not preclude responsiveness to the needs and demands of external stakeholders, they do not promote collective responsiveness to government goals. A Nova Scotia official alluded to this:

We've got these major economic and demographic challenges and we're turning to the universities and saying "you really have to be a part of the solutions." At the level of the presidents, of course, they understand that-but driving down into the institutions and how people think and operate level at the faculty level-it's not [understood]...When we talk about getting better socio-economic outcomes for the province, the presidents will say: "But I can't tell my faculty what to do research on; I can't tell them what to teach; they're independent; they have academic freedom; they pursue their research interests etc." And they'll say to us: "You want them to do more research on Nova Scotia, give them the money." And we say to them: "We're already paying them." But the presidents will say back: "But we can't influence that."

Given the five provincial governments' apparent interest in enlisting universities more directly in contributing to public policy goals, it is perhaps ironic that the foundation of universities' difficulty in meeting this expectation-and of universities' capacity to succeed in fulfilling larger societal missions-is, arguably, their acts. It is the legislation that provides for bicameral governance and that has enabled the development of policies, procedures, and collective agreements that protect academic freedom and the exercise of academic judgement in matters such as hiring. Given provincial governments' current understanding and expectations of universities, provincial legislation may be a fragile foundation for their autonomy and capacity for academic governance. An interviewee who had previously served in senior positions in the Ontario public service commented:

The governance structure is one statute away. Honestly, anyone who has done their thinking about the whereabouts of the governance structure, it's one piece of legislation away, and one party away, and you get in a party, a neo-con party, that wipes this out, it will wipe it out...

This observation about the fragility of the foundation for traditional governance provides insight into the trepidation about the prospect of legislative change expressed by 
some university officials in Quebec. Our interviews in Quebec began a year after the "Maple Spring" of 2012, in which student opposition to the previous Liberal government's plan to raise tuition fees had led to major province-wide protests and contributed to the defeat of that government. In none of the other provinces studied had a university-related issue had such a cataclysmic effect on society and government. In order to chart a path forward after its election, the Parti Québécois government had convened a higher education summit early in 2013 and struck four working groups to recommend policy on key themes. Stakeholders interviewed had very different views on the policy issues at stake. Major changes in the structure of the system were expected or feared, depending on one's vantage point. Provincial student union and faculty union leaders looked forward to a new framework law and council of universities because they believed that these would constrain institutional, board, and executive autonomy and power. Others were concerned about the prospect of more government and/or union and/or student association influence or control over universities. The diversity of perspectives shed light on the changes in the distribution of power and in system structure and dynamics that legislative reform could entail, even in a jurisdiction with traditions of extensive consultation and policy incrementalism.

\section{Conclusion}

Austin and Jones (2015), Jamet (2014), and others have observed that higher education systems with very different traditions and degrees of university autonomy appear to be converging. The traditionally high level of institutional autonomy associated with Anglo-American systems appears to be declining in the face of increasing government regulation and accountability measures, and the findings of our study confirm that provincial systems in Canada are following a similar trend. Every university in our study was experiencing increased requirements for accountability, and increasing pressures to respond to government priorities.

This study found significant variations in the external governance of Canada's major "public" universities in five provinces. The case universities appeared to be coming from and to remain at different points on a state supervision/autonomy continuum. All the universities appeared to be experiencing more provincial supervision and moving away from the autonomous end of the continuum, consistent with observations of convergence on the global stage.

At the same time, the six universities seemed to have the relative autonomy necessary to foster the exercise of academic judgement and academic freedom. The university acts played a major role in protecting this autonomy by assigning responsibility for important matters requiring academic judgement to the university, and more importantly, explicitly to the senate within the internal governance structure of the university. Interviewees also noted that the regular turnover of ministers and deputy ministers, combined with limited policy capacity within provincial ministries, led to an environment in which major government reforms were difficult to initiate or sustain. However, this relative autonomy was viewed as fragile by some interviewees: provincial coordination mechanisms and the governance of universities could be shifted dramatically with a change in government, and major reforms could be only one piece of legislation away. 


\section{Acknowledgements}

Funding for this project was provided by the Social Sciences and Humanities Research Council of Canada.

\section{References}

Alberta. Enterprise and Advanced Education. (2013, April). Guidelines for board of governors members: An introduction to board governance at Alberta's public post-secondary institutions. Retrieved from http://advancededucation.alberta.ca/ media/38300o/board\%20manual\%20complete\%20-\%202013-05-22.pdf

Altbach, P. G. (2015). Massification and the global knowledge economy: The continuing contradiction. International Higher Education, 8o, 4-5.

Altbach, P. G. \& Balan, J. (Eds.). (2007). World class worldwide: Transforming research universities in Asia and Latin America. Baltimore: Johns Hopkins University Press.

Anderson, D., \& Johnson, R. (1998, April). University autonomy in twenty countries. Canberra, Australia: Department of Employment, Education, Training and Youth Affairs.

Ashby, E., \& Anderson, M. (1966). Universities: British, Indian, African. Cambridge, MA: Harvard University Press.

Austin, I., \& Jones, G. (2015). Governance of higher education: Global perspectives, theories and practices. New York, NY: Routledge.

Barendt, E. (2010). Academic freedom and the law: A comparative study. Oxford, UK: Hart Publishing.

Bourdieu, P. (1993). The field of cultural production: Essays on art and literature. Cambridge, UK: Polity Press.

Cameron, D. M. (1991). More than an academic question: Universities, government and public policy in Canada. Halifax, NS: Institute for Research on Public Policy.

Cantwell, B., Marginson, S., \& Smolentseva, A. (Eds.). (2018). High participation systems of higher education. Oxford, UK: Oxford University Press.

Charbonneau, L. (2014, January). Charte des valeurs québécoises: Le débat fait rage. University Affairs/Affaires universitaires. Retrieved from http://www. affairesuniversitaires.ca/opinion/en-marge/charte-des-valeurs-quebecoises-le-debatfait-rage/

Fisher, D., Rubenson, K., Shanahan, T., \& Trottier, C. (Eds.). (2014). The development of postsecondary education systems in Canada: A comparison between British Columbia, Ontario, and Québec 1980-201O. Montreal, QC: McGill-Queen's University Press.

Fournier, M. \& Maheu, L. (1975). Nationalismes et nationalisation du champ scientifique Québécois. Sociologie et sociétés, 7(2), 89-114.

Harman, G. (1991). Governance, administration and finance. In B. R. Clark \& G. R. Neave (Eds.), The encyclopedia of higher education (Vol. 2, pp. 1279-1293). Oxford, UK: Pergamon Press. 
Henkel, M. (2007). Can academic autonomy survive in the knowledge society? A perspective from Britain. Higher Education Research \& Development, 26(1), 87-99.

Jamet,M.(2014).Legouvernement des universités au Québec et en France: Conceptions de l'autonomie et mouvements vers un pilotage stratégique. In T. Chevaillier \& C. Musselin (Eds.), Réformes d'hier et réformes d'aujourd'hui: L'enseignement supérieur recomposé (pp. 21-59). Rennes, France: Presses universitaires de Rennes.

Jones, G. A. (1996). Governments, governance, and Canadian universities. In J. C. Smart (Ed.), Higher education: Handbook of theory and research (Vol 11, pp. 337-371). New York, NY: Agathon Press.

Jones, G. A. (Ed.). (1997). Higher education in Canada: Different systems, different perspectives. New York, NY: Garland.

Lacroix, R., \& Maheu, L. (2015). Leading research universities in a competitive world. Montreal, QC: McGill-Queen's University Press.

Lang, D. W. (2005). Financing higher education in Canada. In S. O. Michael \& M. Kretovics (Eds.), Financing higher education in a global market (pp. 71-118). New York, NY: Algora Publishing.

Levy, D. C. (1986). "Private" and "public": Analysis and ambiguity in higher education. In D. C. Levy (Ed.), Private education: Studies in choice and public policy (pp. 170-192). New York, NY: Oxford University Press.

Marginson, S. (2015). Sustaining resources. International Higher Education, 8o, 11-12.

O'Neill, T. (September 2010). Report on the University System. Halifax: Government of Nova Scotia. Retrieved from https://novascotia.ca/lae/HigherEducation/documents/ Report_on_the_Higher_Education_System_in_Nova_Scotia.pdf

Public Sector Accounting Board (PSAB). (n.d.). 20 questions about the government reporting entity. Toronto, ON: Canadian Institute of Chartered Accountants. Retrieved from http://www.frascanada.ca/standards-for-public-sector-entities/resources/referencematerials/item14956.pdf

Richardson, G., \& Fielden, J. (1997). Measuring the grip of the state: The relationship between governments and universities in selected Commonwealth countries. London, UK: Commonwealth Higher Education Management Service.

Skolnik, M. L. (1997). Putting it all together: Viewing Canadian higher education from a collection of jurisdiction-based perspectives. In Jones, G. A. (Ed.), Higher education in Canada: Different systems, different perspectives (pp. 325-341). New York, NY: Garland.

Thorens, J. (2006). Liberties, freedom and autonomy: A few reflections on academia's estate. Higher Education Policy, 19, 87-110.

\section{Contact Information}

Glen A. Jones

Office of the Dean

Ontario Institute for Studies in Education

University of Toronto

Glen.jones@utoronto.ca 
Julia Eastman is Adjunct Professor in the Gustavson School of Business at the University of Victoria, where she served as University Secretary from 2005 to 2018. Prior to that, she held various administrative positions at Dalhousie University from 1982 to 2003 and was seconded in 2004 to the position of Senior Director (Universities and Colleges) at the Nova Scotia Department of Education. Previously, she worked at the Council of Maritime Premiers in Halifax. She holds a PhD in Higher Education from the University of Toronto and is the co-author (with Daniel Lang) of Mergers in Higher Education (University of Toronto Press, 2001).

Glen A. Jones is Professor of Higher Education and Dean at the Ontario Institute for Studies in Education at the University of Toronto. His research focuses on higher education systems, governance, and academic work. His most recent book, with Ian Austin, is Governance of Higher Education: Global Perspectives, Theories and Practices (Routledge, 2015). Information on his research can be found at www.glenjones.ca.

Olivier Bégin-Caouette is Assistant Professor of Comparative Higher Education at the Université de Montréal. He also holds a PhD in Higher Education (comparative, international, and development education) from the Ontario Institute for Studies in Education (OISE) at the University of Toronto. His research focuses on higher education systems, academic research production, and the internationalization of TVET institutions. More information can be found at http://olivierbegincaouette.yolasite.com.

Sharon X. Li is a sessional program facilitator at Continuing and Professional Learning, Ontario Institute for Studies in Education at the University of Toronto. Her research focuses on comparative higher education and university governance in particular. She received her PhD in Higher Education from the University of Toronto.

Christian Noumi is a PhD candidate at the University of Toronto. His research focuses on comparative higher education. He holds an MA in Higher Education from the University of Kassel (Germany), and a BA in History from the University of Yaounde (Cameroon).

Claude Trottier (Ph.D, University of Toronto) is Professor Emeritus in the Faculty of Education of Université Laval. His areas of specialization are the sociology of education and educational policy analysis. His research focuses on the educational pathways of students, the transition from the education system to the labour market, and the analysis of higher education policies. 